\title{
Determinants of Incident Stunting in Elementary School Children in Endemic Area lodine Deficiency Disorders Enrekang Regency
}

\author{
Nur Abri ${ }^{*}$, Saifuddin Sirajuddin²D, Burhanuddin Bahar ${ }^{2}$, Nurhaedar Jafar ${ }^{2} \mathbb{D}$, Syamsiar S. Russeng ${ }^{3}, Z^{2}$ akaria Zakaria ${ }^{4}$, \\ Veni Hadju² ${ }^{2}$, Abdul Salam², Abdul Razak Thaha ${ }^{2}$ \\ ${ }^{1}$ Master of Public Health Program, Faculty of Public Health, Hasanuddin University, Makassar, Indonesia; ${ }^{2}$ Department of \\ Nutrition, Faculty of Public Health, Hasanuddin University, Makassar, Indonesia; ${ }^{3}$ Department of Occupational Safety and \\ Health, Faculty of Public Health, Hasanuddin University, Makassar, Indonesia; ${ }^{4}$ Department of Nutrition, Poltekkes Kemenkes \\ Makassar, Makassar, Indonesia
}

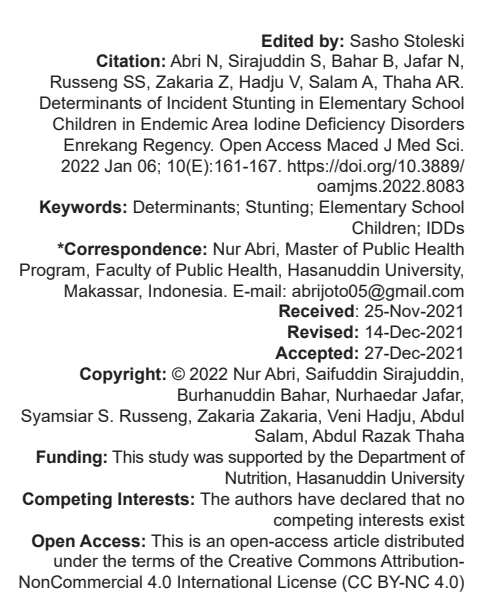

Abstract

BACKGROUND: Stunting is a global health emergency, including in Indonesia. The prevalence of childhood stunting in 2019 in Enrekang amounted to 44.8\%. Enrekang Regency is the area with the highest stunting and is an endemic area. Iodine Deficiency Disorder (IDD) is thought to be correlated with the incidence of stunting.

AIM: This study aims to identify the determinants of stunting in elementary school children in IDDs endemic areas in the Enrekang Regency.

METHODS: An observational analytic study with a cross-sectional approach. The subjects of this study were mothers and their children aged 6-12 years. 100 total samples were collected based on the purposive sampling method. Collecting data using a questionnaire, FFQ, iodine test kit, microtia, and palpation. Data analysis using chisquare and logistic regression.

RESULTS: The results showed that there was a relationship between maternal height $(p=0.020)$, diet $(p=0.049)$ PHBS practice $(p=0.012)$ on the incidence of stunting. While the use of iodized salt $(p=0.510)$ and palpation of the thyroid gland $(p=1000)$ were not associated with stunting. Lack of PHBS practices for children has a 6333-fold chance of experiencing stunting, while stunted mothers have a 5.583-fold chance of giving birth to stunting children.

CONCLUSIONS: There is a relationship between mother's height, child's diet, and PHBS practice with stunting. Analysis of determinants related to the incidence of stunting is very important so that it becomes input and empirical evidence to the regional governments in formulating policies to overcome the problem of stunting, which is the highest in South Sulawesi.

\section{Introduction}

Nutritional status is an important indicator to measure children's quality of life [1]. The physical growth and nutritional status of school-age children (SAC) are very important because they represent the general health status of the entire community [2]. At present, stunting is still a priority for nutritional problems in Indonesia. A child is categorized as stunted if the result of the TB/U measurement is below minus two standard deviations (<-2SD).

Globally, in 2019, it was reported that around 144 million children under five $(21.3 \%)$ were stunted. Of the 144 million children under five in the world who experience stunting, more than half come from lower- and middle-income countries and only a quarter come from low-income countries. More than half of the world's stunted children live in Asia (54\%) while more than a third (40\%) live in Africa.

Indonesia is one of the developing countries that have a high prevalence of stunting. The prevalence of stunting under five in 2018 was $30.8 \%$. The latest report from the 2019 Indonesian Toddler Nutritional Status Study showed the prevalence of stunting based on TB/U was $27.3 \%$. There has been a $3.5 \%$ decline in the past year. The 2019 SSGBI in South Sulawesi showed the prevalence of stunting under five was $30.1 \%$. By district, the highest prevalence of stunting is in Enrekang Regency, which is $44.8 \%$. The latest report shows that the highest prevalence of stunting in Enrekang Regency is in Buntu Batu District, on average above $40 \%$ compared to 12 other sub-districts.

Stunting is strongly associated with several long-term consequences including higher mortality and morbidity rates, poor cognitive growth, school achievement, learning capacity, work capacity, and work productivity [3]. It affects all aspects of children's lives, its effects are not limited to physical well-being but extend to mental, social, and spiritual well-being [2]. Referring to the high prevalence of stunting and its impact, a comprehensive effort is needed. One of the efforts is to know the determinants of stunting. 
Reducing stunting in children is the first of the six goals in the Global Nutrition Targets for 2025. The government through the RPJMN has targeted to reduce stunting from $30.8 \%$ (2018) to $14 \%$ in 2024 . Enrekang Regency is the area with the highest stunting and is an endemic area lodine Deficiency Disorder (IDD) is thought to be correlated with the incidence of stunting. Based on the facts and data above, it is necessary to prove the link between IDD and stunting, so that researchers are interested in knowing the determinants of stunting in elementary school children living in IDD endemic areas in Enrekang Regency.

\section{Methods}

This study is an observational analytic with a school-based cross-sectional design. This research was conducted from July to August 2021, located in Buntu Batu District, Enrekang Regency, South Sulawesi, Indonesia in three villages (Buntu Mondong Village, Potokullin Village, and Latimojong Village). 100 total samples were obtained using purposive sampling. The dependent variable in the study was the incidence of stunting, while the independent variables were maternal height, child's diet, children's PHBS practice, use of iodized salt, and palpation of the thyroid gland. Height data was obtained using microtia, the diet was obtained using a semi-quantitative FFQ questionnaire and PHBS practice was obtained using a questionnaire based on 10 combined indicators of PHBS at household and school levels by the Indonesian Ministry of Health, while the use of salt was obtained with an iodine test kit, and thyroid gland palpation was performed. by the researcher after attending the training. Determination of nutritional status using the WHO AnthroPlus 2007 application. Mother's height is normal if $150 \mathrm{~cm}$. Children's diet refers to the 2019 nutritional adequacy rate based on the child's age and gender. PHBS practice refers to a Likert scale. Determination of salt iodine based on the quality requirements for consumption salt of SNI 30 ppm. Palpation refers to WHO criteria, namely levels 0,1 , and 2. Data were analyzed using the SPSS version 24 program with univariate, bivariate, and multivariate tests. The chi-square test was used to see the relationship between variables and logistic regression to see the magnitude of the influence of the variables.

\section{Results}

Table 1 shows that the most common characteristics of mothers by age are in the age group 31-40 years, $45.0 \%$. The mother's last education
Table 1: Characteristics of mothers of school children

\begin{tabular}{|c|c|c|}
\hline Mother characteristics & $\mathrm{n}$ & $\%$ \\
\hline \multicolumn{3}{|l|}{ Age (year) } \\
\hline $21-30$ & 17 & 17.0 \\
\hline $31-40$ & 45 & 45.0 \\
\hline $41-50$ & 33 & 33.0 \\
\hline $51-60$ & 5 & 5.0 \\
\hline \multicolumn{3}{|l|}{ Education } \\
\hline Not completed in primary school & 5 & 5.0 \\
\hline Elementary School & 34 & 34.0 \\
\hline Junior High School & 27 & 27.0 \\
\hline Senior High School & 18 & 18.0 \\
\hline Diploma/Bachelor & 16 & 16.0 \\
\hline \multicolumn{3}{|l|}{ Profession } \\
\hline Housewife & 53 & 53.0 \\
\hline Planters & 27 & 27.0 \\
\hline Trader & 4 & 4.0 \\
\hline Day Worker & 2 & 2.0 \\
\hline Craftsman & 1 & 1.0 \\
\hline Private Employees & 2 & 2.0 \\
\hline Government employees & 9 & 9.0 \\
\hline Others & 2 & 2.0 \\
\hline \multicolumn{3}{|l|}{ Tribe } \\
\hline Duri & 90 & 90.0 \\
\hline Bugis & 10 & 10.0 \\
\hline \multicolumn{3}{|l|}{ Height $(\mathrm{cm})$} \\
\hline$<150$ & 86 & 86.0 \\
\hline$\geq 150$ & 14 & 14.0 \\
\hline \multicolumn{3}{|l|}{ Number of children } \\
\hline 1 & 5 & 5.0 \\
\hline 2 & 18 & 18.0 \\
\hline 3 & 30 & 30.0 \\
\hline 4 & 22 & 22.0 \\
\hline 5 & 11 & 11.0 \\
\hline 6 & 8 & 8.0 \\
\hline 7 & 5 & 5.0 \\
\hline 10 & 1 & 1.0 \\
\hline Total & 100 & 100.0 \\
\hline
\end{tabular}

was mostly found at an elementary school graduation, $34.0 \%$. The majority of mothers do not work/housewives $53.0 \%$. Almost all the thorns are $90.0 \%$. The majority of mothers with height $<150 \mathrm{~cm}$ were $86.0 \%$. Mothers have at most 3 children, namely $30.0 \%$.

Table 2 shows that most of the children are 10 years old, which is $31.0 \%$. In terms of gender, the most common was male, namely $51.0 \%$. While the nutritional status of children shows that most children with stunting status are $72.0 \%$.

\section{Table 2: Characteristics of children}

\begin{tabular}{lll}
\hline Characteristics of children & $\mathrm{n}$ & $\%$ \\
\hline Age (year) & 11 & \\
7 & 15 & 11.0 \\
8 & 26 & 15.0 \\
9 & 31 & 26.0 \\
10 & 15 & 31.0 \\
11 & 2 & 15.0 \\
12 & & 2.0 \\
Gender & 51 & 51.0 \\
Male & 49 & 49.0 \\
Female & & \\
Nutritional status & 72 & 72.0 \\
Stunting & 28 & 28.0 \\
Normal & 100 & 100.0 \\
Total & & \\
\hline
\end{tabular}

Table 3 shows that the mother's height is $p=0.020$. These results show a $H_{a}$ received and $H_{0}$ is rejected, so it can be concluded that there is a significant relationship between the mother's height with the incidence of stunting. This finding is corroborated because most mothers (86 respondents) are short $(<150 \mathrm{~cm})$. Diet showed a $p=0.049$, this shows $\mathrm{H}_{\mathrm{a}}$ received, so it can be concluded that there is a significant relationship between diet and the incidence of stunting. 22 children with an adequate diet. The practice of PHBS shows the value of $p=0.012$. These 
Table 3: Research variable

\begin{tabular}{|c|c|c|c|c|c|c|c|}
\hline \multirow[t]{3}{*}{ Variables } & \multicolumn{4}{|c|}{ Nutritional status } & \multirow{2}{*}{\multicolumn{2}{|c|}{ Total }} & \multirow[t]{3}{*}{$p$} \\
\hline & \multicolumn{2}{|c|}{ Stunting } & \multicolumn{2}{|c|}{ Normal } & & & \\
\hline & $\mathrm{n}$ & $\%$ & $\mathrm{n}$ & $\%$ & $\mathrm{n}$ & $\%$ & \\
\hline \multicolumn{8}{|c|}{ Mother's Height $(\mathrm{cm})$} \\
\hline$<150$ & 66 & 76.7 & 20 & 23.3 & 86 & 100.0 & \multirow[t]{2}{*}{$0.020^{*}$} \\
\hline$\geq 150$ & 6 & 42.9 & 8 & 57.1 & 14 & 100.0 & \\
\hline \multicolumn{8}{|l|}{ Dietary habit } \\
\hline Deficient & 20 & 90.9 & 2 & 9.1 & 22 & 100.0 & \multirow[t]{2}{*}{$0.049^{* \star}$} \\
\hline Enough & 52 & 66.7 & 26 & 33.3 & 78 & 100.0 & \\
\hline \multicolumn{8}{|l|}{ PHBS Practice } \\
\hline Deficient & 62 & 78.5 & 17 & 21.5 & 79 & 100.0 & \multirow[t]{2}{*}{$0.012^{\star *}$} \\
\hline Good & 10 & 47.6 & 11 & 52.4 & 21 & 100.0 & \\
\hline \multicolumn{8}{|l|}{ Salt Use } \\
\hline Less lodized & 48 & 75.0 & 16 & 25.0 & 36 & 100.0 & \multirow[t]{2}{*}{$0.510^{* \star}$} \\
\hline Enough lodized & 24 & 66.7 & 12 & 33.3 & 64 & 100.0 & \\
\hline \multicolumn{8}{|c|}{ Thyroid Gland Palpation } \\
\hline Goiter Grade 0 & 71 & 71.7 & 28 & 28.3 & 99 & 100.0 & \multirow[t]{2}{*}{$1.000^{\star}$} \\
\hline Goiter Grade 1 & 1 & 100.0 & 0 & 0.0 & 1 & 100.0 & \\
\hline
\end{tabular}

results show that there is a relationship between PHBS practices and the incidence of stunting.

Table 4 shows that the $p$-value of maternal height is $0.011(p<0.05)$. This shows that there is a significant effect between maternal height and the incidence of stunting with a coefficient value of 1720 . In addition, the practice of PHBS in children shows a $p=0.002$. This shows that there is an effect of PHBS practice with the incidence of stunting with a coefficient value of 1.846. Based on the $\exp (B)$ value, it is known that the mother's height $<150 \mathrm{~cm}$ contributes to the incidence of stunting by 5.583 times greater than the mother with a height of $150 \mathrm{~cm}$. While the PHBS practice shows an exp (B) value of 6333. These results indicate that short mothers give birth to 5583 times more stunting children, while children with PHBS practices are less at risk of 6333 times experiencing stunting.

\section{Discussion}

\section{Relationship between mother's height with stunting incident}

Mother's height was obtained from the measurement of the maximum length of the body bones that make up the body axis (the body axis), which was measured from the highest point of the head called the vertex (top of the head) to the lowest point of the calcaneus bone (tuberosities calcanei) called the heel. The mother's height was measured using microtia with an accuracy of $0.1 \mathrm{~cm}$. The results showed that there was a significant relationship between maternal height and the incidence of stunting in children $(p=0.022)$.
This finding is in line with studies reviewed on children in Indonesia, showing consistent evidence that low maternal height is an important determinant of stunting in Indonesia [4]. The same study by Mediani [5] in Indonesia also found that short stature in parents was a significant predictor of stunting in childhood. This research is also supported by the study of Mutiarasari et al. [6] which shows that maternal height is a variable that determines the incidence of stunting in children under five in Palu City, Central Sulawesi. A recent study of children in Ethiopia found that maternal height was significantly associated with severe stunting in children [7].

We found that the majority of short mothers were 86 people $(86.0 \%)$ and short mothers tended to give birth to children stunting, namely 66 children $(76.7 \%)$. The results of the logistic regression showed that short mothers were at risk of giving birth to stunted children 5583 compared to mothers of normal height. This finding appears to indicate transmission of stunting intergenerational where shorter mothers are more likely to give birth to children stunted. A study in Ethiopia found that short mothers $(<150 \mathrm{~cm})$ were 2.5 times more likely to give birth to stunted children when compared to mothers with height $>160 \mathrm{~cm}$ [8]. This shows that stunting in childhood can have an impact on the growth of the next generation.

A study suggested that the father's height can affect a newborn's likelihood of inheriting a gene that affects bone growth throughout pregnancy, while the mother's height can affect a newborn's likelihood of inheriting a gene that affects bone growth at a later period during pregnancy [9]. Mother's height genetically affects child growth [6].

Anthropometry is useful in predicting the nutritional status of individuals related to the general evaluation of health. One of the methods is to measure body height. The short body height of the previous generation will be passed down to the next generation during the growth period. This may cause by genetic and non-genetic factors, such as nutrition [6]. Chronic malnutrition will have an impact on stunting.

This study is not in line with the study of Hanum [10] in Probolinggo which showed that there was no significant relationship between maternal height and the incidence of stunting in children in the Maron sub-district, Probolinggo district $(p=0.704)$. Our study found that short mothers only gave birth to 8 children $(8.0 \%)$ who were stunted.

Table 4: Multivariate analysis

\begin{tabular}{|c|c|c|c|c|c|c|c|c|}
\hline \multirow[t]{2}{*}{ Research variables } & \multirow[t]{2}{*}{ B } & \multirow[t]{2}{*}{ S.E } & \multirow[t]{2}{*}{ Wald } & \multirow[t]{2}{*}{ df } & \multirow[t]{2}{*}{ Sig. } & \multirow[t]{2}{*}{$\operatorname{Exp}(\mathrm{B})$} & \multicolumn{2}{|c|}{$95 \%$ C.I. For $\operatorname{Exp}(B)$} \\
\hline & & & & & & & Lower & Upper \\
\hline Mother's Height & 1.720 & 0.675 & 6.481 & 1 & 0.011 & 5.583 & 1.485 & 20.981 \\
\hline Children's Diet & 1.602 & 0.827 & 3.749 & 1 & 0.053 & 4.962 & 0.981 & 25.107 \\
\hline PHBS Practice & 1.846 & 0.600 & 9.466 & 1 & 0.002 & 6.333 & 1.954 & 20.526 \\
\hline Use of lodized Salt & 0.683 & 0.534 & 1.638 & 1 & 0.201 & 1.980 & 0.696 & 5.636 \\
\hline Thyroid Gland Palpation & 19.500 & 40193.069 & 0.000 & 1 & 1.000 & 2.300 & 0.000 & \\
\hline Constant & -48.155 & 80386.139 & 0.000 & 1 & 1.000 & 0.000 & - & - \\
\hline
\end{tabular}




\section{Relationship between children's diet and stunting incidents}

Dietary habit is the arrangement of foods that are usually eaten including the type and amount of food consumed by a person/group of people in a certain frequency and time. The results showed that there was a significant relationship between children's eating patterns and the incidence of stunting $(p=0.049)$. This finding is in line with the study in Pangkalpinang, Bangka Belitung which showed that there was a relationship between eating habits ( $p=0.040$, OR = 1.55) and stunting in children [11]. Studies in Ethiopia show that low food consumption at the household level has a significant impact on stunting [12]. The same finding in Ghana showed that the lack of minimum eating frequency per child's age $(p=0.007)$ was a significant determinant of stunting in children [13].

We found that consumption of animal source foods and micronutrients at the household level was very rare. It will affect protein deficiency in children. Studies in Ethiopia show that consumption of animal-sourced foods has the potential to affect children's linear growth, and poor diets in energy, protein, and micronutrients can be an important factor in stunting [12]. Our study found that the majority of households were in the food insecurity phase. This may be the reason that the majority of children's consumption of protein sources is inadequate. Children only consume eggs, tempeh, and tofu as a source of protein. Consumption of chicken meat at least once a month and beef/goat only once a year.

Based on the information obtained, most children do not pay much attention to their eating schedule; the majority of children are more active in playing during the Covid-19 pandemic. This has an impact on a low diet. Studies in Egypt show that when children do not eat breakfast and eat $<3$ times a day, the risk of stunting is 4 times greater than children who eat breakfast and eat more than three meals per day $(O R=4.5)$ [2]. Children with low eating habits tend to experience stunting more [11].

We also found that many of the children skipped breakfast. Based on information from the respondent's mother (child), that most of their children do not pay much attention to breakfast. Most children start playing in the morning rather than breakfast. Active play will release energy, energy expenditure without food consumption will have an impact on malnutrition. Research in Egypt showed that children who skipped breakfast or morning snacks did not eat on time and the number of meals $<3$ had a 2 -fold greater risk of experiencing stunting compared to breakfast or morning snacks, ate more than 2 times, and ate on time $(\mathrm{OR}=2.75,2.8,2.06)$ [2].

We also reported that the majority of families ate a monotonous diet. The most common foods are rice, vegetables, fish, tempeh, and tofu. Access to the market requires a journey of 1-2 $h$ so that the type of family food depends on the vendors traveling who ride motorbikes. Studies in Ethiopia show SAC who consumed less than four types of food had a higher risk of stunting than those who consumed four or more types of food. Thus, the probability of stunting was 1.9 times higher among SACs who had dietary diversity scores $<4$ than their counterparts. This may be due to a cerealbased monotonous diet with poor quality, quantity, and frequency of administration that does not meet micronutrient requirements, such as iron, Vitamin B12, folate, and other essential needs for child growth [14]

We conclude that among the underlying causes of stunting in school children in Enrekang Regency are skipping breakfast or eating $<3$ times a day, food insecurity, lack of types of food due to too far access to markets, family income, and lack of nutrition awareness in the entire population. This research is not in line with a study by Olmedo et al. [15] in Argentine children, it showed that there was no relationship between an energy-dense diet and the incidence of stunting.

\section{Relationship between PHBS practices and stunting incident}

According to the Ministry of Health (2017), Clean and Healthy Living Behavior (PHBS) is a collection of behaviors that are practiced based on individual awareness to prevent health problems. The results of this study indicate that there is a significant relationship between PHBS practices and the incidence of stunting $(p=0.012)$. This study is in line with the study of review by Kwami et al. [16] in rural Ethiopia showed there was a significant relationship between handwashing before eating, hand washing with water and soap, and sanitation facilities as structural determinants of stunting. A recent study in Central Java showed that there was a significant relationship between affective PHBS ( $p=0.044)$ and the incidence of stunting in elementary school children [17].

We found that most of the children did not use soap when washing their hands, either before eating or after eating. Children only wash their hands with running water directly or with water that has been collected in a kitchen container. We also found that not a few of them did not use soap after defecating. Ineffective hand washing like this will cause various infectious diseases and infectious diseases related to stunting. A recent study in Donggala Regency showed that there was a significant relationship between the habit of washing hands with soap and the incidence of stunting $(p=0.006)[18]$.

Hands containing microbes if not cleaned properly can be a medium for the entry of microbial organisms into the human body, either through direct contact with the mouth or contact with food and drink. This is a route to gastrointestinal infection, which then affects the absorption of nutrients, thus ultimately resulting in children who are susceptible to stunting [19]. 
The habit of washing hands with soap is a good sanitation step because cleaning hands and fingers using water and soap breaks the chain of microbial transmission. Washing hands with soap are well known as an effort to prevent disease. This is because hands are often the agent that transfers microbes and pathogens from one person to another either through direct or indirect contact. Hands that come into direct contact with human or animal feces or other contaminated body fluids can transfer bacteria, viruses, and parasites to others who may not be aware that these organisms are being transmitted [19].

In addition, we also found that latrine hygiene is a risk factor for stunting in children. Based on field facts, the majority of household latrines do not meet the requirements stipulated by the Regulation of the Minister of Health of the Republic of Indonesia No. 3 of 2014. Research in Tanjung Pinang shows that there is a significant relationship between the availability of latrines that meet hygiene and sanitation standards and stunting in children $(p=0.016)$. One possibility of this relationship is that inadequate toilets lead to the discharge of fecal contaminants directly into the soil [19].

Based on logistic regression, it shows that children who practice PHBS are approximately 6.333 times at risk of experiencing stunting compared to children who practice good PHBS. PHBS policy is an important component of a region as an indicator of a region's success in reducing the incidence of diseases caused by unhealthy behavior. The quality of each human resource is determined by two interrelated factors, namely education, and health. Health is the main requirement in obtaining educational success, while education is one of the factors to achieve good health status for each individual. To create quality human resources, it is necessary to monitor health, starting from an early age.

This study contrasts with a study review in rural Ethiopia which showed that no significant relationship was found between child excreta and stunting $(p=0.659)$. There is an argument that overall handwashing can negate the sanitizing effect [16].

\section{Relationship between the use of iodized salt and the incident of stunting}

Salt is a food additive used by the community as a food flavoring. The main component in salt is sodium chloride $(\mathrm{NaCl})$ by adding potassium iodate $\left(\mathrm{KIO}_{3}\right)$ to the salt when the salt is produced. lodized salt is an effective mass fortification strategy that provides adequate iodine intake for all populations [20]. lodine is essential for thyroid hormone synthesis and is thus required for the normal physical, neurological, and intellectual growth of infants and children, and normal metabolism and function in adults [21]. The results showed that there was no significant relationship between the use of iodized salt and the incidence of stunting in children $(p=0.510)$. This study is in line with the recent study of Li et al. [22] in 35 low- and middleincome countries who found that no use of iodized salt was significantly associated with the likelihood of stunting. lodine is an essential trace element for human growth and development and is required for thyroid hormone synthesis [23].

One-third of the total respondents in this study $(64.0 \%)$ had salt-containing iodine. The most widely used salt was bulk salt (81.0\%), while fine salt (13.0\%), and the least used salt was brick salt $(6.0 \%)$. Based on the analysis of the iodine content in the salt, it was found that brick salt did not contain the most iodine and some of it was krosok/bulk salt. In addition, most households store their salt in a closed container (75.0\%). Proper storage of salt will maintain the iodine content in salt. lodized salt lowers its iodine content if it is not stored under proper conditions such as closed plastic bags, sealed waterproof materials, or closed containers [24]. From this fact, we found that the iodine content of salt was maintained so that there was no correlation between the use of iodized salt and the incidence of stunting.

lodized salt has been introduced in many countries around the world as a sustainable strategy to increase the population level of iodine intake and prevent IDD. Between 1942 and 2020, 123 countries introduced mandatory laws on the iodization of salt. By 2021, 124 countries have laws for mandatory salt iodization and at least 21 countries have laws that allow voluntary salt iodization. Mandatory legislation is considered the most reliable approach to ensuring effective salt iodization, but voluntary salt iodization can also be effective. As a result, $88 \%$ of the global population uses iodized salt. Diets in many countries cannot provide sufficient iodine without fortification of iodized salt [25].

Until now, a better and efficient way to overcome iodine deficiency is to increase iodine intake through the application of universal salt iodization (USI). USI is the iodine of all salt in the country for human and livestock consumption. Salt iodization is the cheapest and easiest way to prevent IDD in all populations. The majority of households use salt that contains effective iodine, so we did not find a correlation between stunting and the use of iodized salt. Other factors influence the incidence of stunting as found in this research.

This study is in contrast to a recent study in Ethiopia which found an association of stunting with iodized salt $(A O R=1.55)$. This shows that the use of non-iodized salt is 1.5 times more likely to be stunted among children whose mothers do not use iodized salt [12].

\section{Relationship between thyroid gland palpation with stunting incident}

Palpation is the traditional method of determining thyroid size. The term "goiter" refers to an 
enlarged thyroid gland. On palpation, each lobe of the thyroid gland has a volume greater than the terminal phalanges of the thumb of the person being examined, which is considered a goiter [26]. Goiter is a classic sign of chronic iodine deficiency.

The results showed that there was no significant relationship between palpation of the thyroid gland and the incidence of stunting $(p=1.000)$. This study is in line with a recent study in Southern Ethiopia which showed a low goiter prevalence and no school children aged 6-12 years had grade 2 goiter [23].

It was found that $64.0 \%$ of respondents used iodized salt (iodine content $\geq 30 \mathrm{ppm}$ ) so that only 1 child out of 100 total respondents was detected as having thyroid gland disorders. We found that the use of iodized salt at the household level prevented the incidence of goiter. This finding is in line with a study in Ethiopia which showed consumption of non-iodized salt had a significant relationship with the development of goiter. Children who use non-iodized salt are 3.12 times more likely to develop a goiter than children who use iodized salt [27]. A recent study in Amhara, Central Ethiopia showed that inappropriate use of iodized salt at the household level was associated with goiter [28].

In general, salt is an easily available source of iodine for a population. However, the iodine content of salt samples varies greatly depending on the source, storage area, packaging method, and the method used for processing the manufacturer. Our findings reveal that most of the households store their salt in closed containers. Proper storage of salt will maintain the quality of iodine in salt. lodized salt reduces its iodine content if not stored under proper conditions [24]. The use of iodized salt and proper storage at the household level also need to be considered to avoid IDD in children. This is one of the pieces of evidence of the absence of a significant relationship between goiter and stunting.

lodine status is a major determinant of the thyroid [29]. As an essential nutrient, iodine plays an important role in the synthesis of thyroid hormones. lodine is an important element that is carried to the body through food intake [30]. Thyroid hormone is essential for bone development and is an important regulator of bone maintenance in adults [31]. Enlargement of the thyroid gland is not the cause of stunting in this finding, but the incidence of stunting is caused by other factors such as those found in this study.

This study is not in line with the findings in Meghalaya, India in 2700 children showing the prevalence of goiter was significantly associated with stunting $(p=0.001)$ in children aged 6-12 years [32]. This study in Amhara, Central Ethiopia which found a significant association between stunting and goiter $(p=$ 0.044 , OR $=1.87$ ) in children aged $10-19$ years. This shows that stunted children have a 1.87-fold chance of goiter compared to normal children [28].

\section{Conclusion}

The results showed that the mother's height, children's diet, and PHBS practices were significantly related to the incidence of stunting. PHBS practices and maternal height were found to have a major influence on the incidence of stunting in elementary school children. Children with fewer PHBS practices are 6333 times more at risk of stunting than children with good PHBS practices. Meanwhile, short mothers are 5583 times more likely to give birth to stunted children compared to mothers of normal height. The use of iodized salt and palpation of the thyroid gland was not found to be associated with stunting.

The contribution of health workers and educators is very important to educate children regarding the importance of PHBS, both across schools and in the community. Fortification and modification of a good diet in children and checking children's height regularly are deemed necessary to break the chain of transmission of stunting across generations from an early age. We suggest that the next researcher measure the height of both parents (father and mother) to see the genetic correlation with stunting.

\section{Acknowledgments}

We thank the Department of Nutrition, Hasanuddin University, for funding this research. We also thank all those who have contributed to this research.

\section{Ethical Statement}

Health Research Ethics Commission, Faculty of Public Health, Hasanuddin University on October 14 with the number: 9190/UN4.14.1/TP.01.02/2021.

\section{References}

1. Dey AK, Nath $A B$. Nutritional status of school going children (6-15 Years) in a Semi-Urban area of Cachar district, Assam. J Evol Med Dent Sci. 2017;6(54):4057-62.

2. Metwally AM, El-Sonbaty MM, El Etreby LA, El-Din EMS, Hamid NA, Hussien HA, et al. Stunting and its determinants among governmental primary school children in Egypt: A schoolbased cross-sectional study. Open Access Maced J Med Sci. 2020;8(B):650-7.

3. Ponum M, Khan S, Hasan O, Mahmood MT, Abbas A, Iftikhar M, et al. Stunting diagnostic and awareness: Impact assessment 
study of sociodemographic factors of stunting among schoolgoing children of Pakistan. BMC Pediatr. 2020;20(1):232. https://doi.org/10.1186/s12887-020-02139-0

PMid:32429876

4. Beal T, Tumilowicz A, Sutrisna A, Izwardy D, Neufeld LM. A review of child stunting determinants in Indonesia. Matern Child Nutr. 2018;14(4):e12617. https://doi.org/10.1111/mcn.12617 PMid:29770565

5. Mediani HS. Predictors of stunting among children under five year of age in indonesia: A scoping review. Glob J Health Sci. 2020;12(8):83.

6. Mutiarasari D, Miranti M, Fitriana Y, Pakaya D, Sari P, Bohari B, et al. A determinant analysis of stunting prevalence on under 5 -year-old children to establish stunting management policy. Open Access Maced J Med Sci. 2021;9(B):79-84.

7. Dewau R. Severe stunting and its associated factors among children aged 6-59 months in Ethiopia; multilevel ordinal logistic regression model. Ital J Pediatr. 2021;47(1):161. https://doi. org/10.1186/s13052-021-01110-8.

PMid:34311750

8. Amaha ND, Woldeamanuel BT. Maternal factors associated with moderate and severe stunting in Ethiopian children: Analysis of some environmental factors based on 2016 demographic health survey. Nutr J. 2021;20(1):18. https://doi.org/10.1186/s12937-021-00677-6 PMid:33639943

9. Sari K, Sartika RA. The effect of the physical factors of parents and children on stunting at birth among newborns in Indonesia. J Prev Med Public Health. 2021;54(5):309-16. https://doi. org/10.3961/jpmph.21.120

PMid:34649393

10. Hanum NH. Relationship between maternal height and a history of complementary feeding with the incidence of stunting in toddlers aged 24-59 months. Amerta Nutr. 2019;3(2):78-84. https://doi.org/10.20473/amnt.v3i2.2019.78-84

11. Julianti E, Elni E. Determinants of stunting in children aged 12-59 months. Nurse Med J Nurs. 2020;10(1):36-45.

12. Tafese Z, Alemayehu FR, Anato A, Berhan Y, Stoecker BJ. Child feeding practice and primary health care as major correlates of stunting and underweight among 6-to 23-month-old infants and young children in food-insecure households in Ethiopia. Curr Dev Nutr. 2020;4(9):nzaa137. https://doi.org/10.1093/cdn/nzaa137 PMid:32923922

13. Appiah CA, Mensah FO, Hayford FEA, Awuuh VA, Kpewou DE. Predictors of undernutrition and anemia among children aged 6-24 months in a low-resourced setting of Ghana: A baseline survey. J Health Res. 2021;35(1):27-37.

14. Getaneh Z, Melku M, Geta M, Melak T, Hunegnaw MT. Prevalence and determinants of stunting and wasting among public primary school children in Gondar town, northwest, Ethiopia. BMC Pediatr. 2019;19(1):207. https://doi.org/10.1186/ s12887-019-1572-X

PMid:31238889

15. Olmedo SI, Román MD, Berra S, Valeggia CR. Food intake and the significance of feeding in Qom children of Northern Argentina. Curr Dev Nutr. 2020;4(11):nzaa158. https://doi. org/10.1093/cdn/nzaa158 PMid:33215054

16. Kwami CS, Godfrey S, Gavilan H, Lakhanpaul M, Parikh P. Water, sanitation, and hygiene: Linkages with stunting in rural Ethiopia. Int J Environ Res Public Health. 2019;16(20):3793. https://doi.org/10.3390/ijerph16203793 PMid:31600942

17. Ariantjelangi L. Clean and healthy living behavior with the stunting events in children in Central Java, Indonesia. Syst Rev Pharm. 2020;11(12):127-33.
18. Hasanudin H, Djaafar T, Saharudin S, Bungawati A. Factors related to the incidence of stunting in nupabomba and Guntarano villages, Tanantovea district, Donggala regency. IOP Conf Ser. 2021;755(1):012035

19. Ahmadi A, Sulistyorini L, Azizah R, Oktarizal H. Association between toilet availability and handwashing habits and the incidence of stunting in young children in Tanjung Pinang city, Indonesia. Malaysia J Med Health Sci. 2020;16(2):215-8.

20. Farebrother J, Naude CE, Nicol L, Sang Z, Yang Z, Jooste PL, et al. Effects of iodized salt and iodine supplements on prenatal and postnatal growth: A systematic review. Adv Nutr. 2018;9(3):219-37.

21. Ershow AG, Skeaff SA, Merkel JM, Pehrsson PR. Development of databases on iodine in foods and dietary supplements. Nutrients. 2018;10(1):100. https://doi.org/10.3390/nu10010100 PMid:29342090

22. Li Z, Kim R, Vollmer S, Subramanian SV. Factors associated with child stunting, wasting, and underweight in 35 low-and middleincome countries. JAMA Netw Open. 2020;3(4):e203386. https://doi.org/10.1001/jamanetworkopen.2020.3386 PMid:32320037

23. Elias E, Tsegaye W, Stoecker BJ, Gebreegziabher T. Excessive intake of iodine and low prevalence of goiter in school age children five years after implementation of national salt iodization in Shebedino woreda, Southern Ethiopia. BMC Public Health. 2021;21(1):165. https://doi.org/10.1186/s12889-021-10215-y PMid:33468112

24. Appiah PK, Yanbom CT, Ayanore MA, Bapula A. Iodine content of salt use after years of universal iodization policy and knowledge on iodized salt among households in the Sissala east municipality in upper West Region Of Ghana. J Food Qual. 2020;2020:1-8

25. Zimmermann MB, Andersson M. Global perspectives in endocrinology: Coverage of iodized salt programs and iodine status in 2020. Eur J Endocrinol. 2021;185(1):R13-21. https:// doi.org/10.1530/EJE-21-0171 PMid:33989173

26. WHO. Assessment of lodine Deficiency Disorders and Monitoring Their Elimination. Geneva: WHO; 2014. p. 1-108.

27. Abebaw B, Oumer A. Determinants of iodine deficiency among school age children in Guraghe Zone, Southwest Ethiopia. Int J Public Health Sci. 2020;9(2):90-6.

28. Zeru AB, Muluneh MA, H Giorgis KK, Menalu MM, Tizazu MA. lodine deficiency disorder and knowledge about benefit and food source of iodine among adolescent girls in the North Shewa Zone of Amhara region. J Nutr Metabol. 2021;2021:8892180. https://doi.org/10.1155/2021/8892180 PMid 33520308

29. Zimmermann MB, Boelaert K. lodine deficiency and thyroid disorders. Lancet Diabetes Endocrinol. 2015;3(4):286-95. https://doi.org/10.1016/S2213-8587(14)70225-6 PMid:25591468

30. Morales-Suárez-Varela M, Peraita-Costa I, Llopis-Morales A, Llopis-Gonzalez A. Assessment of dietary iodine intake in school age children: The cross-sectional ANIVA study. Nutrients. 2018;10(12):1884. https://doi.org/10.3390/nu10121884 PMid:3051388

31. Williams GR, Bassett JH. Thyroid diseases and bone health J Endocrinol Invest. 2018;41(1):99-109. https://doi.org/10.1007/ s40618-017-0753-4 PMid:28853052

32. Bhattacharyya H, Nath CK, Pala S, Medhi GK, Chutia H. lodine deficiency disorders in children in East Khasi Hills district of Meghalaya, India. Indian Pediatr. 2020;57(9):811-4.

PMid:32999109 